Article

\title{
The Impact of Digital Communication and PR Models on the Sustainability of Higher Education during Crises ${ }^{+}$
}

\author{
Umut Ayman *®D, Anıl Kemal Kaya® and Ülfet Kutoğlu Kuruç® \\ Department of Public Relations and Advertising, Eastern Mediterranean University, Famagusta 99450, Cyprus; \\ anil.kemal@emu.edu.tr (A.K.K.); ulfet.kutoglu@emu.edu.tr (Ü.K.K.) \\ * Correspondence: umut.ayman@emu.edu.tr \\ † This article is presented in ICLEL 20.
}

Received: 27 August 2020; Accepted: 2 October 2020; Published: 9 October 2020

\begin{abstract}
Currently, the world is going through a pandemic, COVID-19, that affects the four pillars of organizational sustainability. At this point, institutions' sustainability depends on how they handle crisis communication. It seems that institutions that can adapt themselves to changes regarding the usage of digital communication platforms are survivors, and even winners, of this crisis. The general belief concerning education in developing countries claims that these countries are slow in adapting to technological innovations. Being a developing country, North Cyprus has a multi-cultural environment due to the presence of international students in tertiary education. This study explores how two public and two private universities maintained sustainability in higher education during COVID-19 by discussing the public relations models (PR) that they have used regarding digital communication. This study uses a qualitative content analysis and a quantitative method. The paper asserts that the effective usage of digital communication contributes to the sustainability of universities during this crisis. The findings revealed that the posts (text/image/poster) and videos these universities share are more concentrated on either press agentry or the public information model. Yet, a two-way symmetrical model that maintains dialogue within stakeholders is practiced less than the other PR models. Hence, there is a need for the universities to listen to their stakeholders not only in face to face communication but more through digital communication platforms as well.
\end{abstract}

Keywords: COVID-19 pandemic; crisis management; higher education systems; online communication; PR models

\section{Introduction}

Institutions have gone through drastic changes in the contemporary world to survive and compete with their competitors. This is the case for higher education institutions as well. Every institution tries to survive and achieve organizational objectives in its daily routines by managing relationships with its stakeholders to maintain sustainability. Besides competition with rivals, managing crisis communication with stakeholders plays an important role in sustainable business operations. In the 21st century, sustainability is a vital concept for survival. The term sustainability can be used in different contexts with different meanings. It is one of those complex concepts that is difficult to define specifically. The Cambridge dictionary defines sustainability as "the quality of being able to continue over a period of time" [1]. Organizations need to maintain sustainability to continue to function especially during crises. As Wolff states "sustainability elements became more obvious when the business did not go on as usual, but an unexpected break occurred" [2]. Thus, organizations need to find innovative ways to maintain their sustainability and not to lose their competitive advantage. 
Recently, the world is going through a pandemic, COVID-19, that affects the four pillars of organizational sustainability, namely the human pillar, the social pillar, the environmental pillar, and the economic pillar tremendously.

From the above-mentioned pillars, (1) human sustainability focuses on preserving and improving the human capital in communities. Investments in health and education systems that underline the scope of our study during the coronavirus crisis are vital components of human sustainability. Human sustainability focuses on the importance of anyone directly or indirectly involved in the making of products or the provision of services for broader stakeholders [3]. (2) social sustainability focuses on the social dimension. It tends to maintain and improve social equality and justice. The COVID-19 crisis has become a global concern for social equality and justice. (3) Environmental sustainability is providing the motivation for organizations to judge their environmental consequences. Concerning the environmental pillar, "the fundamental premise of equity and justice is that less inequality and greater justice reduce the alienation of people from their living spaces and, thus, heighten their concern with environmental issues" [4]. (4) Economic sustainability, on the other hand, focuses on regulating the standards of living and economic matters. As Diesendorf posits the principle of sustainable development addresses social and economic improvement that protects the environment and supports equality, and therefore the economy and society and the ecological system are mutually dependent [5]. Due to the impact of the coronavirus crisis the World is experiencing a dramatic economic collapse. "The UN Department of Economic and Social Affairs (UN DESA) estimates that COVID-19 may cause the global economy to shrink by nearly $1 \%$ by the end of 2020" [6]. Finally, environmental sustainability focuses on preserving and improving human conditions through the protection of natural capital. Dunphy, Benveniste, Griffiths, and Sutton describe environmental sustainability as how businesses can achieve positive economic outcomes without doing any harm, in the short- or long-term, to the environment [7]. For businesses and institutions to survive especially during crises, all of these four pillars of sustainability should be maintained. "Importantly, the demand for equity, social, economic and environmental justice is for all people regardless of their origin, race, gender, ethnicity ... and developed and developing societies" [4].

During the COVID-19 pandemic, the success of higher education depends on how universities handle the crisis by considering the four pillars of sustainability as mentioned above. In the executive summary of Policy Brief: Education during COVID-19 and beyond, it is declared that the "COVID-19 pandemic has created the largest disruption of education systems in history, affecting nearly 1.6 billion learners in more than 190 countries and all continents" [8]. Due to the flow of international students, tertiary education becomes one of the fastest-growing service industries of the World. Sustainability in higher education systems will bring sustainability to the global economy, and social and environmental policies. As it is suggested by Bergman et al. “NGOs (non-governmental organizations) or NPOs (non-profit organizations) across the globe have redirected resources toward achieving sustainability goals. Universities more generally, and UNESCO Chairs, in particular, could also make much greater contributions" [9].

How institutions manage to be sustainable in the market depends on how they handle crisis situations. During the COVID-19 pandemic, it seems that almost all sectors get influenced and institutions try to maintain and continue their business operations through well-prepared crisis management plans. Crisis management is a vital function for institutions. During such crises especially in the initial crisis response stage as Coombs [10] suggests, it is essential for an organization to be quick, accurate, and consistent. Coombs further states that quickness and accuracy play an important role in public safety. When public safety is at risk then people need to know what they must do to protect themselves [10]. Sturges refers to this as instructing information [11]. Instructing information needs to be quick, accurate, and consistent to be useful and help organizations to maintain sustainability. Hence, communication, especially transparency in communication, is an important aspect of crisis management. As Avraham and Ketter suggest in the process of handling crisis effectively, a quick response with one simple message, using a single spokesperson, showing transparency, and creating empathy [12] is essential. Yet, Coombs, in a YouTube video by Chatfuel School (Ep.11), posits that 
in crisis response, institutions should not let speed overwhelm their strategy [13]. Hence, to act quickly is important but, while being quick, the organization needs to use an effective crisis response strategy. During crisis response, organizations should not just share quick messages, they should have effective crisis management strategies. In the same video about crisis communication, when Timothy Coombs was asked how social media had changed the crisis communication response, he stated that with the use of new media technologies, the organizations could "adjust their messages based on the public opinion" [13]. Social media creates an interactive communication platform for dialogue. As Coombs suggests organizations should not just communicate; they should listen (listen to Twitter and Facebook) [13]. When you listen to your stakeholders, then you will have a chance to make empathy with them which is a very important skill, especially during such crisis situations.

In this study, concerning the problems that students are facing during this pandemic, it is essential for university administrators to listen to their students, understand their problems, and try to help them not only in their physiological needs but also in their psychological concerns as well. As seen in Figure 1 below, in order to help students to handle their psychological problems; love/ belonging and self-esteem parts of Maslow's hierarchy of needs have to be maintained. Maslow's hierarchy of needs outlines the basic needs of people. When the layers of this pyramid are considered it could be observed that effective communication is an indispensable component to achieve the five levels of Maslow's hierarchy of needs. Effective communication is required to maintain not only the physiological and safety needs but to overcome the social and psychological concerns of university students as well. In order to have a 'sense of connection', two-way communication between various stakeholders of the institutions are essential. Two-way communication enhances the motivation of students in tertiary education. Titrek et al. underline the importance of motivation in international university students' lives for adaptation to their school environments [14]. During such a crisis like the COVID-19 pandemic, in order to make university students feel more motivated, higher education institutions have to use two-way communication effectively through digital communication platforms. Biasutti argues that goodwill and support are relevant feelings for tertiary students during virtual activities [15]. Effective communication, goodwill, and support are essential elements of sustainability in higher education institutions during such crises.

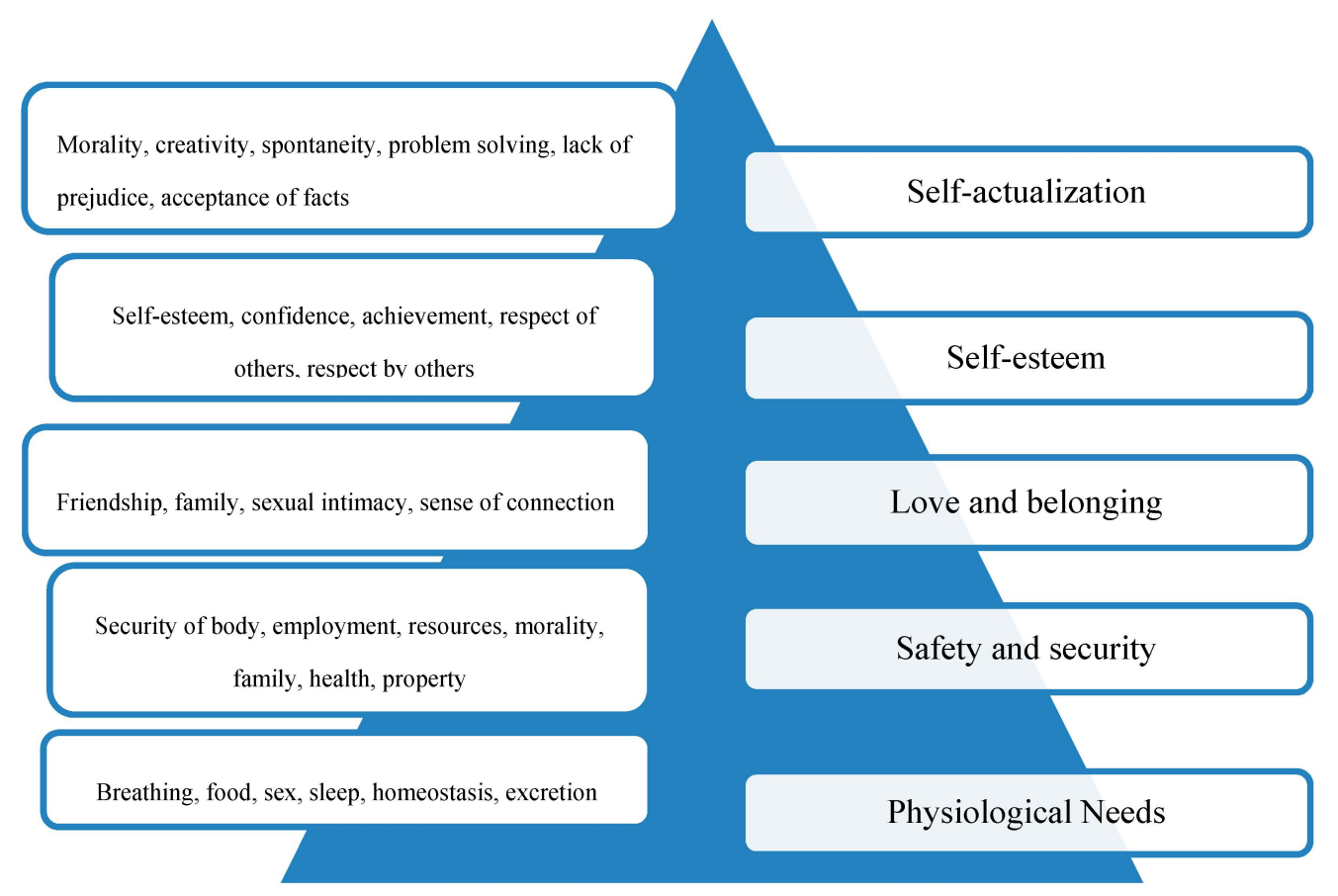

Figure 1. Maslow's Hierarchy of Needs [16]. 
The institutions that can adapt themselves to changes especially related to the applications and usage of digital platforms and online communication tools are survivors, and even winners, of the coronavirus crisis. Global higher education has drastically changed in the last few months due to the coronavirus crisis. Students from the higher education sector all over the world find themselves restricted because of travel cancellations, social distancing issues, quarantines, and campus closures. Since institutions are physically closed and traveling is banned in order to maintain and support higher education, the online medium becomes an inevitable opportunity for tertiary education. The use of the internet and new media technologies have given a chance for universities to implement online education and online communication. In the Policy Brief: Education during COVID-19 and beyond, it has been declared that "this crisis has stimulated innovation within the education sector" [8]. Vladescu states that innovation in education has varied expressions, such as innovative organizational structure, a new teaching method, or computers and communications integration in education [17]. During this crisis as Vladescu points out, universities have implemented a new teaching method which is an online education, and a new way of communication that is online communication.

\section{Background and Aim of the Study}

Higher education is a fundamental and thriving sector for economical sustainability in developing countries, however, there is a bias thought about education concerning developing countries. The general belief concerning education in developing countries is that such countries are slow in adapting to new trends and technological innovations. However, this is not the case for higher education in North Cyprus. The universities here in the wake of the coronavirus outbreak quickly moved to online education. Moreover, in order to sustain their communication, both with their internal and external stakeholders, universities use online communication platforms as well.

"UNESCO estimates that over 1.5 billion students in 165 countries are out of school due to COVID-19. The pandemic has forced the global academic community to explore new ways of teaching and learning" [6]. As aforementioned, one of the major sectors affected by this pandemic is higher education. "By mid-April 2020, 94 percent of learners worldwide were affected by the pandemic, representing 1.58 billion children and youth, from pre-primary to higher education, in 200 countries" [8]. In order to be able to preserve and maintain the activities of this sector, administrators of the worldwide universities decided to move to online education. Following these decisions, the Council of Higher Education in Turkey (YÖK) claims that they are witnessing the urge to move to digital and remote teaching in higher education and adds that the administrators should follow these challenges carefully to keep their students motivated socially, emotionally, and mentally [18]. The measures taken and implemented by YÖK are then taken into consideration by the Ministry of Education of North Cyprus and Higher Education Planning, Evaluation, Accreditation and Coordination Council of North Cyprus (YÖDAK) to be applied to the higher education system in North Cyprus during the coronavirus outbreak.

Effective communication is essential for the sustainability of higher education, especially in such crisis situations. As a developing country, North Cyprus has many political restrictions; yet there is a growing tendency for the higher education sector here. There are twenty-five universities in North Cyprus and it has a multi-cultural environment with lots of international students. Similar to the universities across the globe, the universities in North Cyprus close campus facilities and switch to online education and digital platforms for the dissemination of information in the wake of the COVID-19 crisis. Wolff argues that "in the COVID-19 situation, many in the field of education see digital learning as the solution" [2]. Initially, the major challenges for higher education during the coronavirus pandemic are uncertainty and communication but after the usage and application of digital platforms, these challenges become opportunities like online communication and education.

In order to avoid panic, the universities in North Cyprus maintain educational progress through innovative education systems like switching to online learning. This pandemic forces the university administrators to revise their crisis management plans and to make changes concerning their 
communication strategies and education systems. During such crises, like pandemics, university administrations have to give quick, accurate, and consistent messages to their stakeholders. Openness and transparency in communication and the ability to adapt quickly to the changing crisis situations will help improve higher education institutions in the near future. Higher education institutions have to "act quickly, think innovatively, and work collaboratively to mitigate the impacts of this challenge" [6]. Kutoglu Kuruç and Opiyo state the importance of social media during such crisis situations as platforms for interactive communication [19]. Coombs, Coombs and Holladay, Valentini, Waters et al. [20-23] also emphasize the impact of social media as tools for communication during crisis situations. Moreover, Çelebi, Selçuk, and Peker also claim that social networks have led initially school staff and eventually the society to more active participation [24].

This study aims to describe and explore the sustainability process of the higher education system during the COVID-19 crisis. The paper argues how two public and two private higher education institutions in North Cyprus handle crisis management during the COVID-19 pandemic regarding digital communication and discusses the public relations models (PR) models and the Social Mediated Crisis Communication (SMCC) model they have used online to maintain the sustainability of higher education. The efficiency of what these four universities' have shared, such as text/image/poster posts and videos, are analyzed from the perspective of crisis communication and crisis management. Hence, this study is going to contribute to the literature of crisis management of tertiary education during a global health crisis and serve as a guide for other higher education institutions.

\section{Theoretical Framework}

In this study, for the theoretical background, the four PR models by Grunig and Hunt and the SMCC model were used to investigate the use of PR models of the selected universities in digital communication during this pandemic to maintain sustainability at tertiary education. The models used in the paper are outlined and defined below.

\subsection{Four PR Models by Grunig and Hunt}

As summarized by Theaker, the four PR models by Grunig and Hunt [25] are as follows:

1. The Press Agentry/Publicity model: This PR model is mostly used in show business, celebrity PR, where the main aim is promotion through media coverage.

2. Public information model: This communication model provides information to the public.

3. Two-way asymmetric PR model: This model introduces the idea of two-way communication. However, it is asymmetric because the intended change is in the attitudes or behavior of the audience rather than the organization's practices.

4. Two-way symmetric PR model: This model is sometimes described as the 'ideal' model of public relations. It describes a level of equality of communication where each party is willing to change their behaviors to accommodate the needs of the other ... the symmetric model involves dialogue [26].

\subsection{The Social-Mediated Crisis Communication Model}

Developed by Austin et al. [27], the SMCC model could be used in crisis situations to emphasize the understanding of social media usage. During crisis situations, the users in social media platforms can be categorized as influential social media content creators, social media followers, and social media inactives. From these categories: “(a) influential social media content creators, ... communicate about the crisis via social media; (b) social media followers, ... communicate about the crisis by posting creators' crisis information online and otherwise communicating the content to others both on- and offline; and (c) social media inactives, ... communicate about the crisis by garnering information from traditional media and conveying it via word-of-mouth (WOM) with both the social media content creators and followers, who may, in turn, communicate this content online and offline" [27]. In this 
study, the usage of the four PR models by Grunig and Hunt and the SMCC model by Austin et al. were used to shed light on any significant findings concerning social media usage by two private and two public universities in North Cyprus during the COVID-19 Crisis.

\section{Research problems, Limitations, and Methods}

\subsection{Research Problems}

Crisis communication is an important aspect of institutions' survival and sustainability, especially in the higher education sector. This is clearly observed during COVID-19. During this pandemic, people were under lockdown in their houses and were following what was going on in their countries and the world by using digital communication platforms. Regarding developing countries, there is a bias thought that higher education institutions are slow in adapting to new trends and technological innovations. Moreover, in the literature, there is limited research done about the efficiency of crisis management regarding PR models' perspective in digital communication platforms of universities to maintain sustainability for providing physiological and/or psychological satisfaction to students in developing countries. In this study, the following three research questions (RQ) and two hypotheses $(\mathrm{H})$ were used to shed light on the use and impact of digital communication and PR models on the sustainability of higher education during this pandemic.

RQ1: How do the four most populated universities in North Cyprus communicate with their publics on Facebook (social media platform) during the COVID-19 crisis (the period from 10 March to 30 June 2020)?

RQ2: What is the theme for Facebook shares during the COVID-19 pandemic according to the SMCC model (the period from 10 March to 30 June 2020)?

RQ3: What is the categorization of universities' Facebook shares during the COVID-19 pandemic according to the four PR models by Grunig and Hunt (1984)?

H1: The type of content shares (COVID-19 issues / standard shares) created by universities and disseminated in the digital communication platform (Facebook) were matching with Grunig and Hunt's PR models.

H2: The content of posts (text/image/poster) and video shares created by universities and disseminated in the digital communication platform (Facebook) were matching with Grunig and Hunt's PR models.

\subsection{Limitations of the Research}

This research presents how two public and two private universities in North Cyprus handle crisis communication during the COVID-19 process by using Facebook shares and PR models to maintain the sustainability of higher education. In this paper, online shares were analyzed with the coding sheet developed by authors. This research primarily focused on higher education institutions' digital communication strategies that had been used to communicate with their followers during the period from 10 March to 30 June 2020.

\subsection{Methods}

The present study focuses on two public and two private universities' interactive communication systems on Facebook in North Cyprus. Qualitative and quantitative content analyses were used to explore how the selected universities maintain sustainability during the COVID-19 pandemic and discuss the PR models and the SMCC model the universities have used in the dissemination of their digital communication shares. Considering the combination of Grunig and Hunt's PR models and the SMCC model, a coding sheet was prepared by the authors to make the qualitative dimension of the research. Then, using the coding sheet these four universities' shares were evaluated. In the coding sheet, all shares of these universities were firstly categorized either as COVID-19 related issues or standard shares. Then, each share's content was evaluated regarding the usage of PR models. 
The intention was to explore whether these shares were created consciously regarding the PR models or not, to analyze the social media creators, and to evaluate whether the social media creators had an influence on the social media followers by examining the usage of emotion icons. After analyzing the shares individually, the authors came together to make a cross-check and finalized the coding sheet that was entered by the IBM SPSS Statistics for Windows, Version 21.0 (21.0, IBM, Armonk, NY, USA). The time frame for this research was from 10 March to 30 June 2020. After the evaluation of the contents and themes of all shares, numerical values were used to interpret and analyze how these four universities used the PR models in their social media shares. The numerical data obtained from digital communication platforms contribute to the quantitative method of the study.

\subsection{Population/Sample/Study Group}

The presence of 25 universities in North Cyprus provides a multi-cultural environment with lots of international students. The present study focuses on two public and two private universities' interactive communication systems on Facebook. These universities are chosen because they are the ones with the highest number of students in North Cyprus. The two public universities are Eastern Mediterranean University (EMU) and the European University of Lefke (EUL) whereas the two private universities are Near East University (NEU) and Cyprus International University (CIU). From these four universities, EMU is located in Famagusta, NEU and CIU are in Nicosia, and EUL is in Lefke. Data for this study was collected by researchers through Facebook platforms of the above-mentioned universities during the COVID-19 pandemic. The data checklist used for the content analysis was created by authors and analyzed in SPSS 21 software program.

\section{Findings}

The findings of the research questions and testing of the hypotheses after the analyses of the qualitative and quantitative methods were as follows:

RQ1: How do the four most populated universities in North Cyprus communicate with their publics on Facebook (social media platform) during the COVID-19 crisis (the period from 10 March to 30 June 2020)?

As seen in Table 1 below, a total of 847 shares were used for analyses. From these shares $74.5 \%$ were (text/image/poster) type of posts and $25.5 \%$ were video shares. Out of the 847 shares, $35.2 \%$ of them were related only to COVID-19 issues and $64.8 \%$ were standard shares such as newly opened programs, ranking lists about the success of universities ... That means that despite the crisis, these universities not only shared information concerning the COVID-19 period but also generated standard shares for their followers.

Such as, among all posts in EMU 33.7\% were related to the COVID-19 process and $66.3 \%$ were standard shares, in NEU 18.1\% were COVID-19 shares and $81.9 \%$ were standard shares, in CIU $45.3 \%$ of shares were about COVID-19 and 54.7\% were standard shares, and in EUL $43.3 \%$ of the shares were related with COVID-19 and 56.7\% were about standard shares.

Table 1. Communication with Publics on Facebook (social media platform).

\begin{tabular}{|c|c|c|c|c|c|c|c|}
\hline $\begin{array}{c}\text { Higher } \\
\text { Institutions }\end{array}$ & $\begin{array}{l}\text { Total } \\
\text { Shares }\end{array}$ & $\begin{array}{c}\text { Total } \\
\text { Percentages }\end{array}$ & $\begin{array}{l}\text { COVID-19 } \\
\text { Shares }\end{array}$ & $\begin{array}{l}\text { COVID-19 } \\
\text { Percentages }\end{array}$ & $\begin{array}{l}\text { COVID-19 } \\
\text { Total }\end{array}$ & $\begin{array}{l}\text { Standard } \\
\text { Shares }\end{array}$ & $\begin{array}{c}\text { Standard } \\
\text { Shares Total }\end{array}$ \\
\hline $\begin{array}{c}\text { (EMU) } \\
\text { (text/image/poster) } \\
\text { posts }\end{array}$ & 192 & $(68.1 \%)$ & $\begin{array}{c}86 \\
\text { (Turkish/English) }\end{array}$ & $(90.5 \%)$ & & $\begin{array}{c}106 \\
(56.7 \%)\end{array}$ & \\
\hline $\begin{array}{l}\text { (EMU) video } \\
\text { shares }\end{array}$ & 90 & $(31.9 \%)$ & 9 & $(9.5 \%)$ & & $81(43.3 \%)$ & \\
\hline $\begin{array}{c}\text { (NEU) } \\
\text { (text/image/ } \\
\text { poster) posts }\end{array}$ & 91 & $(53.2 \%)$ & 21 (90\% Turkish) & $(67.7 \%)$ & & $70(50 \%)$ & \\
\hline $\begin{array}{l}\text { (NEU) video } \\
\text { shares }\end{array}$ & 80 & $(46.8 \%)$ & 10 & $(32.3 \%)$ & & $\begin{array}{c}60(42 \%) \\
\text { live chat } \\
10(8 \%) \\
\text { standard }\end{array}$ & \\
\hline
\end{tabular}


Table 1. Cont.

\begin{tabular}{|c|c|c|c|c|c|c|c|}
\hline $\begin{array}{c}\text { Higher } \\
\text { Institutions }\end{array}$ & $\begin{array}{c}\text { Total } \\
\text { Shares } \\
\end{array}$ & $\begin{array}{c}\text { Total } \\
\text { Percentages }\end{array}$ & $\begin{array}{c}\text { COVID-19 } \\
\text { Shares }\end{array}$ & $\begin{array}{c}\text { COVID-19 } \\
\text { Percentages }\end{array}$ & $\begin{array}{l}\text { COVID-19 } \\
\text { Total }\end{array}$ & $\begin{array}{l}\text { Standard } \\
\text { Shares }\end{array}$ & $\begin{array}{c}\text { Standard } \\
\text { Shares Total }\end{array}$ \\
\hline EMU Total shares & 282 & $100 \%$ & 95 & $100 \%$ & $33.7 \%$ & 187 & $66.3 \%$ \\
\hline NEU Total shares & 171 & $100 \%$ & 31 & $100 \%$ & $18.1 \%$ & 140 & $81.9 \%$ \\
\hline $\begin{array}{l}\text { (CIU) (text/image/ } \\
\text { poster) posts }\end{array}$ & 67 & $(89.3 \%)$ & $\begin{array}{c}31 \\
\text { (Turkish/English) }\end{array}$ & $(91.2 \%)$ & & $36(87.8 \%)$ & \\
\hline (CIU) video shares & 8 & $(10.7 \%)$ & 3 & $(8.8 \%)$ & & $5(12.2 \%)$ & \\
\hline CIU Total shares & 75 & $100 \%$ & 34 & $100 \%$ & $45.3 \%$ & 41 & $54.7 \%$ \\
\hline $\begin{array}{c}\text { (EUL) } \\
\text { (text/image/poster) } \\
\text { posts }\end{array}$ & 281 & $(88.1 \%)$ & $\begin{array}{l}126 \text { (different post } \\
\text { shares for } \\
\text { Turkish/English) }\end{array}$ & $(91.3 \%)$ & & $\begin{array}{c}155 \\
(85.6 \%)\end{array}$ & \\
\hline $\begin{array}{l}\text { (EUL) video } \\
\text { shares }\end{array}$ & 38 & $(11.9 \%)$ & 12 & $(8.7 \%)$ & & $26(14.4 \%)$ & \\
\hline EUL Total shares & 319 & $100 \%$ & 138 & $100 \%$ & $43.3 \%$ & 181 & $56.7 \%$ \\
\hline Total & 847 & & 298 & & $35.2 \%$ & 549 & $64.8 \%$ \\
\hline
\end{tabular}

As seen in Table 1 above, EMU, CIU, and EUL all preferred to use posts (text/image/poster) more than video shares in their digital communication whereas NEU tried to balance the share types more (53.2\% posts and $46.8 \%$ video shares) than the other universities. When explored individually, $68.1 \%$ of EMU's posts were (text/image/poster) types and 31.9\% were video shares. On the other side, from CIU's shares, $89.3 \%$ were (text/image/poster) posts and $10.7 \%$ were video shares, and $88.1 \%$ of EUL's shares were (text/image/poster) posts and $11.9 \%$ were video shares.

During the COVID-19 crisis, EMU had 95 COVID-19 related shares; 90\% of these shares were (text/image/poster) posts. NEU has 31 shares about the COVID-19 issue and $67.7 \%$ of these shares were (text/image/poster) posts. Since these universities have many international students, they should be careful about the medium of instruction they used. However, analyses showed that from these universities only three of them cared about the medium of the language they had used for communication on digital platforms. NEU did not consider the language barrier for their international students and mainly used Turkish, the native language.

RQ2: What is the theme for Facebook shares during the COVID-19 pandemic according to the SMCC model (the period from 10 March to 30 June 2020)?

During the lockdown period, all these universities commonly shared COVID-19 related information such as decisions of the council of ministry, universities senate decisions, and contact numbers for emergencies such as hospitals, universities' administrations, and the ministry of health. The only difference among universities was that the two public universities, EMU and EUL focused on posts concerning university decisions during this period more. They tried to make their followers easily follow up on what university administrations did for their students' sustainability. NEU focused on public spots and videos to inform the students/followers how they would protect themselves during the COVID-19 pandemic and mostly emphasized the importance of wearing masks, washing hands, and keeping a distance. On the other side, CIU tried to provide some public information for their students/ followers about how they could save their energy while staying at home and how to preserve their health during the pandemic period. Until May 2020, the universities mostly preferred to focus on (text/image/poster) posts for their prospective students. Considering the SMCC model, it could be said that NEU's, CIU's, and EUL's social media units acted as influential social media content creators during the promotional shares meaning that these universities decided about the shares type and the theme of shares they used. EMU's social media unit, however, acted as a partially influential social media content creator whereby the faculties and departments were integrated into the promotional post creations.

RQ3: What is the categorization of universities' Facebook shares during the COVID-19 pandemic according to the four PR Models by Grunig and Hunt (1984)? 
As seen in Table 2, considering Grunig and Hunt's PR models, EMU used 195 press agentry (69.1\%), 82 public information (29.1\%), and five two-way symmetrical (1.8\%) PR model in the creation of the contents for the total shares during the period from 10 March to 30 June 2020. NEU used 141 press agentry (82.5\%), 24 public information (14\%), 6 two-way asymmetrical (3.5\%) PR model in the creation of the contents for the total shares. CIU used 43 press agentry (57.3\%), 24 public information $(32 \%)$, and 8 two-way asymmetrical (10.7\%) PR model in the creation of the contents for the total shares and finally EUL used 214 press agentry (67.1\%), 73 public information (22.9\%) and 32 two-way asymmetrical (10\%) PR model in the creation of the contents for the total shares.

Table 2. Communication with Publics on Facebook with Grunig and Hunt's public relations (PR) models.

\begin{tabular}{|c|c|c|c|c|c|c|}
\hline $\begin{array}{l}\text { Higher } \\
\text { Institutions }\end{array}$ & Total Shares & $\begin{array}{l}\% \text { of Total } \\
\text { Shares }\end{array}$ & $\begin{array}{l}\text { COVID-19 } \\
\text { Shares }\end{array}$ & $\begin{array}{l}\text { Grunig and Hunt's } \\
\text { PR Models }\end{array}$ & $\begin{array}{l}\text { Standard } \\
\text { Shares }\end{array}$ & $\begin{array}{l}\text { Grunig and Hunt's } \\
\text { PR Models }\end{array}$ \\
\hline $\begin{array}{l}\text { EMU post } \\
\text { shares }\end{array}$ & 192 & $(68.1 \%)$ & 86 & $\begin{array}{c}63(73.3 \%) \text { press agentry } \\
23(26.7 \%) \text { public } \\
\text { information }\end{array}$ & 106 & $\begin{array}{c}58(54.7 \%) \text { press agentry } \\
48(45.3 \%) \text { public } \\
\text { information }\end{array}$ \\
\hline $\begin{array}{l}\text { EMU video } \\
\text { shares }\end{array}$ & 90 & $(31.9 \%)$ & 9 & $\begin{array}{c}4(44.4 \%) \text { public } \\
\text { information } \\
5(55.6 \%) \text { two-way } \\
\text { symmetry }\end{array}$ & 81 & $\begin{array}{c}7(8.6 \%) \text { public } \\
\text { information } \\
74(91.4 \%) \text { press agentry }\end{array}$ \\
\hline $\begin{array}{l}\text { NEU post } \\
\text { shares }\end{array}$ & 91 & $(53.2 \%)$ & 21 & $\begin{array}{c}15(71.4 \%) \text { press agentry } \\
6(28.6 \%) \text { public } \\
\text { information }\end{array}$ & 70 & $\begin{array}{c}63 \text { press agentry } \\
7 \text { public information }\end{array}$ \\
\hline $\begin{array}{l}\text { NEU video } \\
\text { shares }\end{array}$ & 80 & $(46.8 \%)$ & 10 & $\begin{array}{c}4(40 \%) \text { public } \\
\text { information } \\
6(60 \%) \text { two-way } \\
\text { asymmetry }\end{array}$ & 70 & $\begin{array}{c}63(90 \%) \text { press agentry } \\
7(10 \%) \text { public } \\
\text { information }\end{array}$ \\
\hline $\begin{array}{l}\text { CIU post } \\
\text { shares }\end{array}$ & 67 & $(89.3 \%)$ & 31 & $\begin{array}{c}15(48.4 \%) \text { public } \\
\text { information } \\
13(41.9 \%) \text { press agentry } \\
3(9.7 \%) \text { two-way } \\
\text { asymmetry }\end{array}$ & 36 & $\begin{array}{c}7(19.4 \%) \text { public } \\
\text { information } \\
29(80.6 \%) \text { press agentry }\end{array}$ \\
\hline $\begin{array}{l}\text { CIU video } \\
\text { shares }\end{array}$ & 8 & $(10.7 \%)$ & 3 & $\begin{array}{c}3(100 \%) \text { two-way } \\
\text { asymmetry }\end{array}$ & 5 & $\begin{array}{c}1(20 \%) \text { press agentry } \\
2(40 \%) \text { public } \\
\text { information } \\
2(40 \%) \text { two-way } \\
\text { asymmetry }\end{array}$ \\
\hline $\begin{array}{l}\text { EUL post } \\
\text { shares }\end{array}$ & 281 & $(88.1 \%)$ & 126 & $\begin{array}{c}34(27 \%) \text { public } \\
\text { information } \\
92(73 \%) \text { press agentry }\end{array}$ & 155 & $\begin{array}{c}117(75.5 \%) \text { press } \\
\text { agentry } \\
38(24.5 \%) \text { public } \\
\text { information }\end{array}$ \\
\hline $\begin{array}{l}\text { EUL video } \\
\text { shares }\end{array}$ & 38 & $(11.9 \%)$ & 12 & $\begin{array}{c}12(100 \%) \text { two-way } \\
\text { asymmetry }\end{array}$ & 30 & $\begin{array}{c}5(19.2 \%) \text { press agentry } \\
1(3.8 \%) \text { public } \\
\text { information } \\
20(77 \%) \text { two-way } \\
\text { asymmetry }\end{array}$ \\
\hline
\end{tabular}

Universities created the content of their (text/image/poster) posts and videos on social media platforms during this crisis. When analyzed according to the SMCC model, some of these posts were effective and get the attention of their followers while the others were not. The effectiveness of the posts or videos could be evaluated by followers' reactions under the shares. Emotion icons shared by the university students under posts and videos were used to give an idea concerning their perceptions towards social media shares. The students at tertiary education when they got affected by the social media shares of their universities, shared their reactions either as like, love, laugh, sad, or angry. Thus, social media followers gave various emotional reactions to the content of the shares of the above-mentioned universities. Hence, it could be said that the emotion icons shared by the tertiary students could be considered as feedback which is a necessary aspect of two-way communication. As Coombs suggests organizations should not just communicate, they should listen [13]. Since the university administrations nowadays could not meet with their students because of the lockdown, it was essential to follow their students' reactions in digital communication platforms. This helped the university administrators to have an idea about their students' feelings, concerns, expectations, and likes and dislikes. The analyses of reactions were important to understand the psychological 
concerns of students, especially during such crisis situations. This was an important aspect for universities because they could help their students when they were in need or when they were experiencing problems. Analyzing the responses of the university students in social media shares could help the higher education institutions to understand the social concerns and psychological situations of their students. This was vital for supporting and motivating them which were inevitable elements of maintaining sustainability in higher education especially during such crisis times. Examples of content that universities mainly shared were: providing general information about governmental decisions, university application during the crisis process, online education system, online chats, celebration messages for the special days, campus photos, students and graduates videos of academic success ... etc. From these shares, some influenced the followers' emotions while others did not. When the follower numbers of universities were compared, the shares with 100 emotional reactions or less were considered to be quite low and were not taken into consideration. Before categorizing the most liked shares it was essential to mention the number of followers of these universities. EMU had the majority of followers on their official Facebook page with 177,839 members. NEU had 147,226 followers, EUL had 19,734 and CIU had 52,081 followers consecutively.

Considering the shares that received 100 emotional reactions or more and analyzing them according to the SMCC model, there were differences from one university to the other. The share named "Disinfection against coronavirus" at EMU post got the majority of the emotional reactions (924 reactions). The post designed for students who would come from abroad during the quarantine application period and had to stay in quarantine dormitories without any fee was the second most liked post and the third most-liked post was the one portraying the photos of the university administrative staff in supporting and helping students during the COVID-19 crisis by donating food and hygiene products. These posts were preferred because, during the pandemic, the psychology of tertiary students was affected. Hence, they focused more on the shares related to health, security, food, and protection which were considered to be the basic needs. The content of these posts really affected the followers' emotions. The most popular posts where the majority of EMU followers shared their emotional reactions were the ones that EMU announced the new, online education system, university decisions for current students; academic and administrative staff during the COVID-19 pandemic, the success of EMU in the world ranking lists, accredited faculties and departments, graduates students' videos, promotion videos, campus photos, the posts against racism and inequity and special days greetings messages. On the other hand, NEU received the most liked posts when they announced that they produced an alternative respirator. This post received 5354 likes; the second most popular share was a video prepared as a public spot that disseminated the message to stay at home and to be safe. This video took 854 likes and the third most preferred share was about engineers who produced equipment for medical officials to be used for coronavirus protection. It received 668 likes. Similar to EMU, NEU's most popular shares were the ones concerning the COVID-19 process, their online education system, and the university decisions for current students.

CIU and EUL had fewer followers on social media platforms than the other two universities yet, they tried to touch to their followers' emotions as well. For CIU the most liked post was a photo of the campus with the caption "missing the campus". This share got 286 likes and the second most preferred one was another photo of the campus hoping that all stakeholders of the higher education institution would be safe and healthy which took 239 likes and the third most-liked post was the one against racism and inequity which took 209 likes. They generally shared info about their online education system and university decisions for current students as well. Eventually, in EUL, the most preferred share was about the university's support for their students donating food and hygiene products which took 289 likes. The second most-liked post was the campus photo taken in 1993 that took 122 likes and the third most preferred share was an academic staff's bulletin which was about how spaces would be used safely after COVID-19. That bulletin was about interior architecture and it took 108 followers' likes. Since evaluating the likes of the shares could be an important aspect in the calculation of engagement rate, in this study just emotional reactions of followers were analyzed to how 
the content of these shares affected the emotions of the stakeholders. This communication would help the university administrators to grasp the needs and concerns of their students both physiologically and psychologically during the COVID-19 crisis.

H1: The type of content shares created by universities and disseminated in the digital communication platform (Facebook) were matching with Grunig and Hunt's PR models.

This hypothesis was used to prove whether social media creators' used PR models consciously in the creation of these shares. As seen in Tables 3 and 4, out of the 847 shares the universities preferred to use the press agentry model more than the other PR models which meant focusing on one-way communication that used publicity and promotion was very popular among the universities. The second most popular PR model was public information that was also based on one-way communication using press release technique to distribute institutional information. In other words, this model was used to prepare accurate content of shares. The important thing here was that during the COVID-19 pandemic, it was vital for higher education institutions to provide accurate information to their stakeholders. Another PR model that the universities used during the pandemic was a two-way asymmetrical model that had two-way imbalanced communication that is intended to persuade the stakeholders of the universities to act in accordance with the institutions' desire and a few two-way symmetrical models were used to show a balanced communication among stakeholders.

Table 3. Type of content shares (COVID-19 issues/standard shares) in relation to PR models Crosstabulation.

\begin{tabular}{|c|c|c|c|c|c|c|c|}
\hline & & & \multicolumn{4}{|c|}{ Shares Relate to PR } & \multirow[b]{2}{*}{ Total } \\
\hline & & & $\begin{array}{l}\text { Press } \\
\text { Agent }\end{array}$ & $\begin{array}{l}\text { Public } \\
\text { Info }\end{array}$ & $\begin{array}{c}\text { Two-Way } \\
\text { Asymmetry }\end{array}$ & $\begin{array}{l}\text { Two-Way } \\
\text { Symmetry }\end{array}$ & \\
\hline \multirow{6}{*}{$\begin{array}{l}\text { type of } \\
\text { share }\end{array}$} & \multirow{3}{*}{ Covid-19 } & Count & 183 & 86 & 24 & 5 & 298 \\
\hline & & $\%$ within type of share & $61.4 \%$ & $28.9 \%$ & $8.1 \%$ & $1.7 \%$ & $100.0 \%$ \\
\hline & & $\%$ within shares relate to $P R$ & $30.9 \%$ & $42.4 \%$ & $52.2 \%$ & $100.0 \%$ & $35.2 \%$ \\
\hline & \multirow{3}{*}{ Standard } & Count & 410 & 117 & 22 & 0 & 549 \\
\hline & & $\%$ within type of share & $74.7 \%$ & $21.3 \%$ & $4.0 \%$ & $0.0 \%$ & $100.0 \%$ \\
\hline & & $\%$ within shares relate to PR & $69.1 \%$ & $57.6 \%$ & $47.8 \%$ & $0.0 \%$ & $64.8 \%$ \\
\hline \multirow{3}{*}{\multicolumn{2}{|c|}{ Total }} & Count & 593 & 203 & 46 & 5 & 847 \\
\hline & & $\%$ within type of share & $70.0 \%$ & $24.0 \%$ & $5.4 \%$ & $0.6 \%$ & $100.0 \%$ \\
\hline & & $\%$ within shares relate to PR & $100.0 \%$ & $100.0 \%$ & $100.0 \%$ & $100.0 \%$ & $100.0 \%$ \\
\hline
\end{tabular}

Table 4. Universities' shares in relation to PR models Crosstabulation.

\begin{tabular}{|c|c|c|c|c|c|c|c|}
\hline & & & \multicolumn{4}{|c|}{ Shares Relate to PR } & \multirow[b]{2}{*}{ Total } \\
\hline & & & $\begin{array}{l}\text { Press } \\
\text { Agent }\end{array}$ & $\begin{array}{l}\text { Public } \\
\text { Info }\end{array}$ & $\begin{array}{l}\text { Two-Way } \\
\text { Asymmetry }\end{array}$ & $\begin{array}{c}\text { Two-Way } \\
\text { Symmetry }\end{array}$ & \\
\hline \multirow{12}{*}{ university } & \multirow{3}{*}{ EMU } & Count & 195 & 82 & 0 & 5 & 282 \\
\hline & & $\%$ within university & $69.1 \%$ & $29.1 \%$ & $0.0 \%$ & $1.8 \%$ & $100.0 \%$ \\
\hline & & $\%$ within shares relate to PR & $32.9 \%$ & $40.4 \%$ & $0.0 \%$ & $100.0 \%$ & $33.3 \%$ \\
\hline & \multirow{3}{*}{ NEU } & Count & 141 & 24 & 6 & 0 & 171 \\
\hline & & $\%$ within university & $82.5 \%$ & $14.0 \%$ & $3.5 \%$ & $0.0 \%$ & $100.0 \%$ \\
\hline & & $\%$ within shares relate to $P R$ & $23.8 \%$ & $11.8 \%$ & $13.0 \%$ & $0.0 \%$ & $20.2 \%$ \\
\hline & \multirow{3}{*}{$\mathrm{CIU}$} & Count & 43 & 24 & 8 & 0 & 75 \\
\hline & & $\%$ within university & $57.3 \%$ & $32.0 \%$ & $10.7 \%$ & $0.0 \%$ & $100.0 \%$ \\
\hline & & $\%$ within shares relate to $P R$ & $7.3 \%$ & $11.8 \%$ & $17.4 \%$ & $0.0 \%$ & $8.9 \%$ \\
\hline & \multirow{3}{*}{ EUL } & Count & 214 & 73 & 32 & 0 & 319 \\
\hline & & $\%$ within university & $67.1 \%$ & $22.9 \%$ & $10.0 \%$ & $0.0 \%$ & $100.0 \%$ \\
\hline & & $\%$ within shares relate to $P R$ & $36.1 \%$ & $36.0 \%$ & $69.6 \%$ & $0.0 \%$ & $37.7 \%$ \\
\hline \multirow{3}{*}{\multicolumn{2}{|c|}{ Total }} & Count & 593 & 203 & 46 & 5 & 847 \\
\hline & & $\%$ within university & $70.0 \%$ & $24.0 \%$ & $5.4 \%$ & $0.6 \%$ & $100.0 \%$ \\
\hline & & $\%$ within shares relate to PR & $100.0 \%$ & $100.0 \%$ & $100.0 \%$ & $100.0 \%$ & $100.0 \%$ \\
\hline
\end{tabular}

As seen in Table 5, the Pearson chi-square value is $24.485^{\mathrm{a}} \mathrm{df}=3 p=0.000<0.05$ so it shows that PR models and the type of content shares (COVID-19 issue/standard) that universities use to have a close relationship meaning that social media creators of institutions decide to use either press agentry, public information, two-way asymmetric or two-way symmetric model while creating their content shares. Taking the press agentry model into consideration, it could be said that $30.9 \%$ were used for 
COVID-19 concerns and $69.1 \%$ were used for standard shares. On the other hand, $42.4 \%$ of the public information model shares were COVID-19 related issues and 57.6\% were standard shares. For the two-way asymmetrical model, 52.2\% were about COVID-19 issues and 47.8\% were about standard shares and lastly, the ideal model which is a two-way symmetrical model was used only for COVID-19 related issues. Thus, it could be said that the type of content shared on Facebook created by the universities matched Grunig and Hunt's PR models therefore it could be said that H1 was accepted.

Table 5. Chi-Square Tests for H1.

\begin{tabular}{cccc}
\hline & Value & Df & Asymp. Sig. (2-Sided) \\
\hline Pearson Chi-Square & $24.485^{\mathrm{a}}$ & 3 & 0.000 \\
Likelihood Ratio & 25.414 & 3 & 0.000 \\
Linear-by-Linear Association & 21.926 & 1 & 0.000 \\
N of Valid Cases & 847 & & \\
\hline
\end{tabular}

a. 2 cells $(25.0 \%)$ have expected count less than 5 . The minimum expected count is 1.76 .

H2: The content of posts (text/image/poster) and video shares created by universities and disseminated in the digital communication platform (Facebook) were matching with Grunig and Hunt's PR models.

As seen in Table 6, out of the 847 shares of these universities, the number of posts used was more than the number of video shares, yet in the content of the video shares the asymmetric and symmetric models of PR have been used more compared to the content of the posts. As the idea of post and video sharing is different, it could be seen that the PR models to be used were decided according to that criteria. Of the press agentry model, $75.9 \%$ was used for posts and $24.1 \%$ was used for video shares. On the other hand, considering the usage of the public information model, $87.7 \% \%$ were posts and $12.3 \%$ were video shares. Regarding the two-way asymmetrical model, $6.5 \%$ were about posts and $93.5 \%$ were about video shares and lastly, the two-way symmetrical model was used only for video shares $(100 \%)$.

Table 6. University content of posts (text/image/poster) and video shares in relation to PR Models Crosstabulation.

\begin{tabular}{|c|c|c|c|c|c|c|c|}
\hline & & & \multicolumn{4}{|c|}{ Shares Relate to PR } & \multirow[b]{2}{*}{ Total } \\
\hline & & & $\begin{array}{l}\text { Press } \\
\text { Agent }\end{array}$ & $\begin{array}{l}\text { Public } \\
\text { Info }\end{array}$ & $\begin{array}{l}\text { Two-Way } \\
\text { Asymmetry }\end{array}$ & $\begin{array}{l}\text { Two-Way } \\
\text { Symmetry }\end{array}$ & \\
\hline \multirow{6}{*}{ shares } & \multirow{3}{*}{ Posts } & Count & 450 & 178 & 3 & 0 & 631 \\
\hline & & $\%$ within shares & $71.3 \%$ & $28.2 \%$ & $0.5 \%$ & $0.0 \%$ & $100.0 \%$ \\
\hline & & $\%$ within shares relate to $\mathrm{PR}$ & $75.9 \%$ & $87.7 \%$ & $6.5 \%$ & $0.0 \%$ & $74.5 \%$ \\
\hline & \multirow{3}{*}{ Video } & Count & 143 & 25 & 43 & 5 & 216 \\
\hline & & $\%$ within shares & $66.2 \%$ & $11.6 \%$ & $19.9 \%$ & $2.3 \%$ & $100.0 \%$ \\
\hline & & $\%$ within shares relate to PR & $24.1 \%$ & $12.3 \%$ & $93.5 \%$ & $100.0 \%$ & $25.5 \%$ \\
\hline \multirow{3}{*}{\multicolumn{2}{|c|}{ Total }} & Count & 593 & 203 & 46 & 5 & 847 \\
\hline & & $\%$ within shares & $70.0 \%$ & $24.0 \%$ & $5.4 \%$ & $0.6 \%$ & $100.0 \%$ \\
\hline & & $\%$ within shares relate to $\mathrm{PR}$ & $100.0 \%$ & $100.0 \%$ & $100.0 \%$ & $100.0 \%$ & $100.0 \%$ \\
\hline
\end{tabular}

As seen from Table 7, the Pearson chi-square value is $145.668^{\mathrm{a}}, \mathrm{df}=3 p=0.000<0.05$ so it shows that there is a close relationship between the content of posts/video shares in relation to the PR models used by the universities. For posts, the public information model and press agentry model that was preferred. These models were focused on one-way communication. The two-way symmetrical model that maintains two-way communication was used only for video shares. Thus, it could be said that $\mathrm{H} 2$ was accepted. 
Table 7. Chi-Square Tests for hypothesis 2 (H2).

\begin{tabular}{cccc}
\hline & Value & Df & Asymp. Sig. (2-Sided) \\
\hline Pearson Chi-Square & $145.668^{\text {a }}$ & 3 & 0.000 \\
Likelihood Ratio & 132.994 & 3 & 0.000 \\
Linear-by-Linear Association & 36.373 & 1 & 0.000 \\
N of Valid Cases & 847 & & \\
\hline a. 2 cells $(25.0 \%)$ have expected count less than 5. The minimum expected count is 1.28.
\end{tabular}

\section{Discussion and Conclusions}

The crisis management strategies of the universities during COVID-19 are applied after the governmental decisions. During this pandemic, among the publics that exist in social media platforms, influential social media content creators focus on creating crisis information for the others who are the social media followers and social media inactives to consume the information either directly through social media platforms or indirectly through WOM as discussed by Austin et al. [27]. Hence, it is vital for universities in North Cyprus to act as influential social media content creators to contribute to the dissemination of valid, accurate, and quick information to their stakeholders. The dissemination of such information through digital communication platforms of the universities in North Cyprus during the COVID-19 pandemic enhances their communication with their students and contribute greatly to the human and social pillars of organizational sustainability that eventually help to maintain the economic sustainability of higher education in North Cyprus with the satisfaction of the prospective students. At the initial stage of the pandemic, the major challenges for the institutions in higher education are uncertainty and communication. The effective use of digital platforms helps to pursue the communication process during this crisis. Hence, digital communication contributes to crisis management that helps to maintain the sustainability of universities during this pandemic.

In this study, it could be affirmed that the major universities in North Cyprus are using digital platforms quite frequently to communicate with their stakeholders to maintain sustainability during the COVID-19 crisis. However, universities use their Facebook accounts differently. The analyses show that out of the 847 shares, the four universities mostly prefer to use $74.5 \%$ (text/image/poster) type of posts however among the shares used only $35.2 \%$ of them are related to COVID-19 issues. Meaning that despite the crisis period, universities continue generating some standard shares as well. Since these universities have many international students it is not unexpected to find out that three of them give attention to the medium of the language they use (EMU, CIU, EUL) on digital platforms while they communicate with their followers. During the lockdown period, all these universities commonly share COVID-19 related information. The only difference among these universities is that the public universities focus on shares related to university decisions during this period more than the private universities. Taking the SMCC model into consideration, it seems that NEU's, CIU's and EUL's social media units act as influential social media content creators during the promotional shares. This situation applies to COVID-19 related issues as well except for the council of ministry's decision shares.

According to the categorization of the four PR models, EMU mainly uses both press agentry and public information models in their social media communication. On the other hand, NEU, CIU, and EUL, mostly prefer to use the press agentry model. It is observed that only EMU uses a two-way symmetrical model while they create the content of social media shares. The findings reveal that the posts that the universities share with their stakeholders concentrate more on either press agentry (publicity model) or the public information model. The videos mostly use either public information or two-way asymmetrical PR models. Yet the two-way symmetrical PR model, which is considered to be the ideal model that maintains dialogue within the stakeholders which is a vital communication model especially during crisis situations, is practiced less than the other PR models by the above-mentioned universities. As the hypotheses discussed in detail under the findings part of the research show $\mathrm{H} 1$ and $\mathrm{H} 2$ are accepted. In other words, universities' type of content shares (COVID-19 
issues/standard) and PR models they use have a close relationship (H1) and also universities content of posts (text/image/poster) and video shares and PR models they use also have a close relationship (H2). In other words, hypotheses analyses prove that concerning the COVID-19 related issues, higher education institutions use all PR models by Grunig and Hunt. Additionally, they prefer to use one-way communication like the public information model and press agentry model for posts (text/image/poster) and they use two-way communication for video shares. Contrary to the bias thought concerning the usage of PR models in developing countries, the shares related to COVID-19 totally concentrate on a two-way symmetrical PR model which is the ideal model.

In conclusion, it could be said that to maintain the physiological, social, and psychological needs of the tertiary students, two-way communication between the universities and the students needs to be implemented. As Coombs states, organizations should not just communicate. They should listen as well [13]. In this study, it is revealed that during such a crisis, there is a need for universities to listen to the needs and concerns of their students not only through face-to-face communication in person but through the digital communication platforms as computer-mediated communication as well. The universities' social media planners have to be attentive concerning the content of the posts they will share. Just posting the shares every day at the right time and the right place may not be enough to provide attention or to understand the followers. Higher education institutions must be careful about the content of their shares and use effective communication strategies to support their followers emotionally. Analyzing the post engagement rate might contribute to the success of the shares. Online communication via social media platforms not only contributes to the physiological needs but, as Maslow's hierarchy of needs demonstrates [16], also contributes to the psychological concerns of social media users.

\section{Recommendations for Future Study}

A future study could be administered by using both quantitative and qualitative research methodology to examine what sort of online PR models are used by universities before the COVID-19 pandemic and to make a comparison of digital communication strategies before and after the COVID-19 crisis. Also, a survey could be conducted to explore the perceptions of tertiary students concerning the impacts of the usage of digital communication platforms of universities during crisis situations. Moreover, the students' satisfaction concerning the use of PR models and digital communication strategies during this period can also be explored.

Author Contributions: All authors contributed equally to the text. All authors have read and agreed to the published version of the manuscript.

Funding: This research received no external funding.

Conflicts of Interest: The authors declare no conflict of interest.

\section{References}

1. Cambridge Dictionary. Available online: https:/dictionary.cambridge.org/dictionary/english/sustainability (accessed on 25 July 2020).

2. Wolff, L.A. Sustainability Education in Risks and Crisis: Lessons from Covid-19. Sustainability 2020, 12, 5205. [CrossRef]

3. Benn, S.; Dunphy, D.; Griffiths, A. Organizational Change for Corporate Sustainability, 3rd ed.; Routledge: London, UK, 2014.

4. Eizenberg, E.; Jabareen, Y. Social Sustainability: A New Conceptual Framework. Sustainability 2017, 9, 68. [CrossRef]

5. Diesendorf, M. Sustainability and Sustainable Development. In Sustainability: The Corporate Challenge of the 21st Century; Dunphy, D., Benveniste, J., Griffiths, A., Sutton, P., Eds.; Allen \& Unwin: Crows Nest, Australia, 2000; pp. 19-35. 
6. United Nations Academic Impact, COVID-19 and Higher Education: Learning to Unlearn to Create Education for the Future. Available online: https://academicimpact.un.org/content/covid-19-and-higher-educationlearning-unlearn-create-education-future (accessed on 4 May 2020).

7. Dunphy, D.; Griffiths, A.; Benveniste, J.; Sutton, P. Sustainability: The Corporate Challenge of the 21st Century; Allen \& Unwin: Crows Nest, Australia, 2000.

8. Policy Brief: Education during COVID-19 and Beyond/August 2020, United Nations Sustainable Development Group. Available online: https://www.un.org/development/desa/dspd/wp-content/uploads/sites/22/2020/08/ sg_policy_brief_covid-19_and_education_august_2020.pdf (accessed on 22 August 2020).

9. Bergman, Z.; Bergman, M.M.; Fernandes, K.; Grossrieder, D.; Schneider, L. The Contributions of UNESCO Chairs toward Achieving the UN Sustainable Development Goals. Sustainability 2018, 10, 4471. [CrossRef]

10. Coombs, W.T. Ongoing Crisis Communication: Planning, Managing, and Responding, 3rd ed.; Sage: Thousand Oaks, CA, USA, 2012.

11. Sturges, D.L. Communicating through crisis: A strategy for organizational survival. Manag. Commun. Q. 1994, 7, 297-316. [CrossRef]

12. Avraham, E.; Ketter, E. Media Strategies for Marketing Places in Crisis: Improving the Image of Cities, Countries and Tourist Destinations, 1st ed.; Elsevier: Amsterdam, The Netherlands, 2008; ISBN 978-0-7506-8452-1.

13. Coombs, T. How to Adjust Your Brand's Social Media Strategy during a Crisis (Chatfuel School/Ep.11). Available online: https://m.youtube.com/watch?v=dI5xMVpGE_E (accessed on 3 July 2020).

14. Titrek, O.; Erkiliç, A.; Süre, E.; Güvenç, M.; Pek, N.T. The Socio-cultural, Financial and Education Problems of International Postgrduate Students in Turkey. Univers. J. Educ. Res. 2016, 4, 160-166. [CrossRef]

15. Biasutti, M. A comparative analysis of forms and wikis as tools for online collaborative learning. Comput. Educ. 2017, 107, 158-171. [CrossRef]

16. Maslow's Hierarchy of Needs. Available online: https://tr.123rf.com/photo_52014063_maslow-s-hierarchyof-needs-represented-as-a-pyramid-with-the-more-basic-needs-at-the-bottom.-vector.html (accessed on 13 July 2020).

17. Vladescu, I. The impacts of using ICT in the educational process today. New Trends Issues Proc. Humanit. Soc. Sci. 2017, 4, 123-127. Available online: www.prosoc.eu (accessed on 10 July 2020). [CrossRef]

18. Saraç, Y. Turkish Higher Education in Days of Pandemic, Anadolu Agency. Available online: https://covid19. yok.gov.tr/Sayfalar/HaberDuyuru/opinion-turkish-higher-education-in-days-of-pandemic.aspx (accessed on 21 April 2020).

19. Kutoglu Kuruç, U.; Opiyo, B. Social media usage and activism by non-western budding PR Professionals during crisis communication. Corp. Commun. Int. J. 2020, 25, 98-112. [CrossRef]

20. Coombs, W.T. Applied Crisis Communication and Crisis Management: Cases and Exercises; Sage Publications: Thousand Oaks, CA, USA, 2014.

21. Coombs, W.T.; Holladay, S.J. The Handbook of Crisis Communication; Wiley-Blackwell: Hoboken, NJ, USA, 2010.

22. Valentini, C. Is Using Social Media 'Good' for the Public Relations Profession? A Critical Reflection. Public Relat. Rev. 2015, 41, 170-177. [CrossRef]

23. Waters, R.D.; Tindall, N.T.J.; Morton, T.S. Media Catching and the Journalist-Public Relations Practitioner Relationship: How Social Media Are Changing the Practice of Public Relations. J. Public Relat. Res. 2010, 22, 241-264. [CrossRef]

24. Çelebi, N.; Selçuk, G.; Peker, H.S. A study on the Use of Social Networks by Turkish and German University Students in the Globalization. In Proceedings of the 4th International Conference on Lifelong Education and Leadership for All, ICLEL 2018, Wroclaw, Poland, 3-5 July 2018.

25. Grunig, J.E.; Hunt, T. Managing Public Relations; Holt, Rinehart \& Winston: New York, NY, USA, 1984.

26. Theaker, A. The Public Relations Handbook, 3rd ed.; Routledge: New York, NY, USA, 2008.

27. Austin, L.; Liu, B.F.; Jin, Y. How audiences seek out crisis information: Exploring the social-mediated crisis communication model. J. Appl. Commun. Res. 2012, 40, 188-207. [CrossRef]

(C) 2020 by the authors. Licensee MDPI, Basel, Switzerland. This article is an open access article distributed under the terms and conditions of the Creative Commons Attribution (CC BY) license (http://creativecommons.org/licenses/by/4.0/). 